\title{
ASPECTS OF FINANCIAL EQUILIBRIUM ANALYSIS AND ITS IMPLICATIONS IN MANAGEMENT DECISIONS
}

\author{
Daniela Cristina Solomon \\ "Vasile Alecsandri” University of Bacău \\ daniela.solomon@ub.ro \\ Iulia Andreea Bucur \\ “Vasile Alecsandri” University of Bacău \\ iuliaandreea.bucur@gmail.com
}

\begin{abstract}
Considering the impact of risk factors in the economic environment, this study provides to all users of financial information a possible pattern for analyzing the financial equilibrium, designed to clarify the importance of dynamic analysis of indicators characterizing the financial equilibrium of an enterprise, expressed on absolute values, especially for managers in decision-making on future work, aimed at achieving pre-established strategic and tactical objectives. Practice has shown that the management cannot be based on intuition and routine but on a scientific analysis, on a thorough knowledge of the existing situation, as well as on the identification of vulnerabilities and opportunities for development. In order to promote a rational policy concerning business growth and achieving economic and financial satisfactory results, the company's management grants a special importance to the financial diagnosis. The support of financial analysis is the balance sheet that allows developing financial diagnosis on the financial equilibrium conditions and creditworthiness, objectives that allow the evaluation of the independence of the firm and its market value.
\end{abstract}

\section{Keywords}

balance sheet; financial equilibrium; liquidity; working capital; necessary working capital; net treasury

\section{JEL Classification}

M41; M51

\section{Introduction}

Theory and practice of financial management of the enterprise recognizes three objectives: financial stability, profitability and economic growth. Assessment of basic financial equilibrium of a company is subject to any financial analysis, regardless of the category of users to whom it is intended. In light of shareholder interests it is considered that financial equilibrium is respected if the return on such investment balances the risk they are exposed to. This representation of financial equilibrium is directly related to the objective of shareholders that consists of maximizing the enterprise value. In light of the interests of company managers, assessing financial equilibrium is connected, as in the case of shareholders too, to the objective of maximizing the enterprise value, at which there are added financial equilibrium flexibility criteria, economic growth, financial autonomy and power. For company's creditors, assessing the financial balance is related with getting their claims reimbursed and receives the proper remuneration. Creditors are based on a static analysis of patrimony type and on providing guarantees paying higher importance on concepts of solvency, liquidity of assets and chargeability of debts, as well as different ways to quantify the ability to repay. 
Traditionally, financial analysis is aiming to detect how to achieve financial equilibrium on the short term (objective of the balance sheet analysis) and cash accumulation steps, namely profitability of the company (objective of the analysis based on the income statement). The balance sheet summarizes heritage status of the company at a given time, while profit and loss account allows identifying of economic and financial flows of input, processing and output of the considered period.

Financial and economic analysis, through the analysis of financial equilibrium indicators has the purpose of valorification the information provided by accounting on the basis of which conclusions will be drawn on the effectiveness of activity of the entity. Good organization of treasury management is an essential element of the success of any business, that cannot run normally if the entity does not have cash to pay its obligations when due. The approach ends with determining the strengths and weaknesses concerning the company's activities and measures to be applied in order to achieve short and long term objectives.

For the study of indicators characterizing financial equilibrium there are used quantitative research methods (positivist) and qualitative. Among quantitative research methods are used methods of examination and measurement of phenomena, since the aim is to collect accounting information to interpret the following results, and numerical methods due to the fact that the analytical results will be obtained by applying certain formulas calculation. "Qualitative research methods are due to the need of scientific observation of human interaction and specific skills in one area or another.” (Andone et al, 2013)

Financial equilibrium indicators, namely the net situation, working capital, necessary working capital, net treasury, must answer to questions related to "financial health" of society and its security margin, the correlation between the duration of receivable and payment term debts, and how the company manages the availability of bank accounts and into cash, namely the existence of financial equilibrium by rhythmic collection of receivables and rapid rotation of current assets, this being the central point of our approach.

\section{General considerations on financial equilibrium indicators}

Generally, the equilibrium means stability of a situation, a harmony between the components of a system, which on a financial plan involves harmonizing financial resources of the entity with its financial needs (Paraschivescu et al, 2013).

Financial equilibrium can be defined by the company's ability to secure payment of debts previously contracted without interruption, including debt incurred in implementing the current object of activity, or tax law, in its collections, such that it can avoid the risk of bankruptcy (Căruntu, 2011).

\subsection{Balance sheet - a starting point in determining the financial equilibrium indicators}

The support of financial equilibrium is the balance sheet analysis, the main event of financial reporting that may be in the form of painting in which economic goods, rights and obligations of the entity are presented in the form of a tie, reflecting the balance of assets and liabilities or as property list, model imposed by the Romanian accounting reform concerning The accounting regulations compliant with Directive IV of the EEC, International Accounting Standards and International Financial Reporting standards. 
Being prepared based on the accounting year-end balance sheet should provide information needed to calculate the economic and financial equilibrium indicators as well as information about property management company. Information provided by balance sheet is indispensable to financial analysis by the fact that it helps determine financial equilibrium, liquidity and solvency of an economic entity and to make comparison analyses concerning company's position relative to its main competitors.

In specific literature we can identify the following types of balance sheet used in the financial analysis: financial balance sheet, functional balance sheet, "Pool de fonds" balance etc.

Financial balance sheet is a traditional financial analysis support which ends with the description of company's assets with the purpose of heritage evaluation that may interest both owners and lenders. The logic is based on the criterion of increasing liquidity of asset and increasing chargeability of passives. Intuitively, it is understood that the financial equilibrium of the company depends, on the one hand, on its chargeability degree of obligations, and, on the other hand, on the degree of liquidity of their rights; their liquidation is a means of honoring them others (Colasse, 2009). Increasing liquidity of active stations is their availability of increasingly high for them to become "liquid" and to meet the needs of the company, at the forefront of asset there are fixed values (intangible assets, tangible, financial), the least liquid that are called stable or permanent allocations, then there are mentioned the more liquid elements, called temporary or cyclical allocation (stocks, receivables, availability). Ranking passive positions in the order of increasing chargeability signifies the fact that funding source chargeability is related to its maturity, the first posts being the slowest in chargeability, namely own equity, then loans for a long time known as financial liabilities.

These, together with equity capital, form permanent (stable) equity. It follows then all other debts faster due (suppliers, lenders, short term loans, social and tax obligations) with a maturity of less than one year contracted for the current operating activities that are also called debt service. Building financial accounts, from the balance sheet, imply compliance with the principles and rules that allow ordering according to short and long term criterion. Among the constituents of the balance sheet, the distinction between those that remain on the enterprise disposal on the long-term (over one year) and those that belong only for short-term (under one year).

Given that the financial statement is optical closure based, unlike the balance sheet based on the fundamental concept (principle) business continuity, financial balance sheet construction involves a series of corrections to items in the balance sheet, such as: removing items fictitious asset or non-values (elements that have no economic value in liquidation case and items that represent activated expenses, such as constituation expenses, research and development expenses etc.) elimination of existing assets and liabilities in the balance sheet adjustment (items which relate to future periods and will not exist in the event of closure). Achieve financial balance sheet imply making corrections based on information from related and principles of assessment and regrouping posts according seniority criterion.

The failure to comply with the principle of financial equilibrium by financing assets from temporary resource, it shows triple nature risks, namely: interest rate risk, materialized in the fact that any increase in market interest rates applied to new loans erode the company's performance; refinancing risk, linked to banks' ability to refuse further funding company given that a company has no financial stability is risky for the bank; the risk of losing the company decision-making autonomy in relation to the bank, unable tied loan company to recontracted absolutely required loans for its operation (Mironiuc, 2009). 
From the analysis in terms of criticism and chargeability appeared functional analysis that has been developed by the bankers authors Meunier, Barolet and Boulmer in 1970 and promoted by the Central Bank Balances in France in the 1970s (Colasse, 2009).

The construction of functional balance sheet that regroups the major functions of the company: investment, mining, finance, treasury, is based on a set of principles and rules created in order to highlight the uses and resources appropriate to each operating cycle of the company, the grouping of posts being related to the operations of posts made by the company in relation to the nature, purpose or function. Design principles for functional balance sheet refers to the following aspects: expression balance sheet posts to net value (the original value), which requires the inclusion of amortization and provisions in equity, being the enterprise's self-financing resources, the concept of stability that takes into consideration the duration heritage stations, they differ from the concept of consistent financial balance sheet; a long-term loan will remain in financial assets of the company, regardless of its maturity, as long-term debts that will not be written as short-term debts, regardless their maturity; in structuring functional balance stations should be considered the damage principle that allows describing life cycles that make up the enterprise and financial equilibrium arising from them so you can see how they used her resources.

The structure allows highlighting two categories of uses in assets, one related with the actual operation and another independent from the production cycle, and in passive two categories of resources, some generated by operating and some others, without connection to it.

In the context of functional analysis from 1980s faced criticism on the role assigned to the Treasury that it is not only the result of reconciling the need for working capital and working capital so it appeared the balance sheet "pool de fonds" or "economic balance sheet" (Colasse, 2009) which provides information on the funding policy and enterprise's investment without giving too much information on the risk of bankruptcy.

Regardless of optics in which the assessment is made, the balance sheet is the "starting point" in asseser's activity, but "can only give information with static character, insufficient for a complete assessment, because it expresses heritage asset items carrying values (book values), without taking into account normal market conditions in the determination of fair market value” (Petrescu, 2012). Balance sheet as O.M.P.F. (Order of the Ministry of Public Finance) No. 3055/2009 is adapted and meet financial analysis oriented on management, based on ordering assets according to increasing liquidity, and capitals in decreasing chargeability order (debts to be paid within a period of up to one year before the debt to be paid in a for more than one year, followed by equity).

Type "list" balance sheet approved by the Order of the Ministry of Public Finance No. 3055/2009 highlights the net heritage situation or net debt computed as two divisions sheet:

E. Net current assets, respectively net current liabilities, that highlights the existing ( + ) and deficit (- ) of working capital;

F. Total assets - current liabilities, which put in evidence heritage situation, uninfluenced by debt situation with pay maturity more than 1 year.

These indicators offers useful information about the situation of firms, being appreciated by specialists, easy to understand and use in comparative analysis even by less prepared staff in conducting complex financial and economic analysis. 


\subsection{Indicators of financial equilibrium}

Financial equilibrium is the ideal state that every company aspires and for its assessment we start from calculating the following indicators expressed in absolute values: net asset presentation, working capital, necessary working capital and net treasury (Petrescu, 2012).

A. Net Assets Presentation expresses the book value of the rights owners, shareholders and creditors have on the company:

\section{Net Asset Presentation $=$ Assets - Total Liabilities}

In the case of the winding, the net situation becomes equal to the sum of net equity and expresses the value of activities at a time, its value being determined by excluding deferred income and provisions:

\begin{tabular}{|c} 
Net Asset \\
Presentation
\end{tabular}$\quad=\left(\begin{array}{c}\text { Total } \\
\text { assets }\end{array}-\begin{array}{c}\text { Current } \\
\text { liabilities }\end{array}\right)-\begin{gathered}\text { Debts over } \\
1 \text { year }\end{gathered}-$ Provisions

\section{$\underset{\text { Presentation }}{\text { Net Asset }} \quad=$ Position F $-\mathbf{G}-\mathbf{H}$}

The increase of the net situation would increase the equity and results in increasing profitability and financial independence of the company.

B. Working capital (WC) characterize the balance/imbalance of financial enterprises at a given time, expressing the permanent capital surplus over the value of net immobilised assets, which serves to finance current assets, particularly those intended to operate. By Working Capital the financial health of an economic entity is estimated and the financial equilibrium conditions are measured, therefore, "the financial equilibrium resulting from the confrontation of liquidities that determines the flow of future receipts and chargeability obligations that determine future payments” (Păvăloaia, 2009).

There are two ways of determining the working capital:

a) difference:

\begin{tabular}{|cccc|}
\hline $\begin{array}{c}\text { Working } \\
\text { Capital }\end{array}$ & $=\begin{array}{c}\text { Permanent } \\
\text { Capital }\end{array}$ & $\begin{array}{c}\text { Net Immobilised } \\
\text { Assets }\end{array}$ \\
\hline $\begin{array}{c}\text { Working } \\
\text { Capital }\end{array}$ & $=$ & $\begin{array}{c}\text { Net current assets/ } \\
\text { net current liabilities }\end{array}$ & $=$ Position E \\
\hline
\end{tabular}

The amount of working capital can be positive or negative and reflects the existence or absence of a safety margin firms.

Increased working capital can be determinate on the one hand by increased permanent capital (emission of new shares, bonds, new long-term loans) and on the other hand by reduced net assets (titles sales, disinvestment and assets assignment). Enterprise security margin increases, a greater proportion of current assets being financed from permanent equity. Depression of the working capital is caused by depression of permanent capital (term loans or bonds reimbursement) and increased net assets (investments). A revolving stationary fund reflects stagnation of the company that can be temporary or on long term, having different causes.

Theoretically, a revolving fund should be positive, which does not mean that in some cases there cannot be a negative working capital without compromising the proper functioning of the enterprise. 
A positive working capital of the company signifies the maintaining of financial equilibrium, allowing to ensure a minimum level of circulation assets strictly necessary for its function (minimum stocks, minimum credit union fund) current asset being higher than short-term liabilities (net current assets > short term debts) in the sense that on the account of payable asset there can be paid short-term debts, equivalent with the fact that permanent resources are provided to cover at least the stable users.

$\square$ A null revolving fund translates a pressure on liquidities and corresponds to a certain weakness of the company in terms of solvency.

- A negative working capital is a signal of not-payment risk for the enterprise, which will have plenty of good permanent equity financing to assure assets or has lower short-term debt that will not be able to pay. This issue frequently occurs in the retail sector, where the rate of inventory turnover is very fast (under one month) and there are significant supplier credits. In practice, it is generally thought that the working capital industrial enterprise has to represent the value of 1-3 months turnover.

Analysis of working capital must be completed with the study of necessary working capital.

C. The need for working capital is a dynamic indicator of financial equilibrium, its size is dependent on several factors: the nature of the activity sector, operating cycle duration, the level and evolution of turnover, rate of inflation, the cost of production level, the operating liabilities arising from obligations of the enterprise to suppliers, staff, state budget (Mironiuc, 2009).

Necessary Working Capital include, on the one hand, stocks (raw materials, finished and semi-products) whose value enclose manufacturing costs and, on the other hand, claims to be funded from working capital. Necessary Working Capital (NWC) reflects the current equilibrium of the company, more unstable than the working capital and it is determined as the difference between current assets (exclusive availability) and short term debts (excluding current bank loans) as shown in formula:

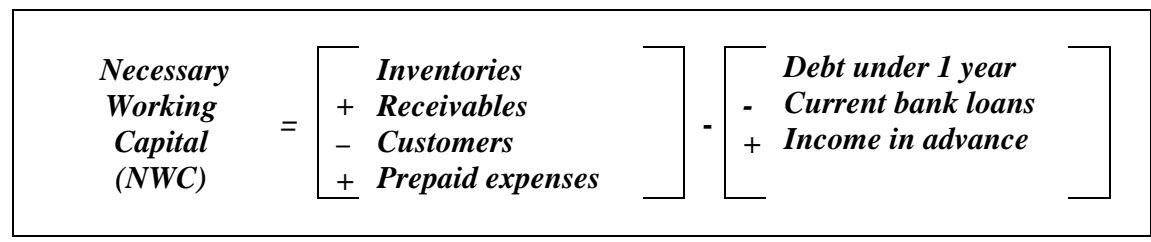

Necessary Working Capital (NWC) designates the enterprise's financial needs, generated by the execution of repetitive operations that make current operating cycle of the company (buy, sales, pay their salaries), whose total cost should be at least partially covered by stable resources (working capital). It represents money that must run in the enterprise to ensure the operation, financing according assets that ask expenses that will be recovered from customers when paying bills.

The need for working capital can be positive or negative. If:

$\square$ NWC $>\mathbf{0}$, reflects a surplus of assets resulting from the acceleration of receipts and payments relaxation, namely a favourable difference between the duration of the recovery of claims and the payment of providers and is a normal situation where the result of the increasing demand for financing investment of the operating cycle. Economic practice has shown, however, that when the need for working capital is greater than zero indicates a negative gap between inventory liquidation and collection of receivables and operating liabilities liability for the 
purposes of revenue slowdown and accelerate payments, a situation that is not conducive to the development firms.

$\square$ NWC < 0, reflects an additional temporary resources toward current assets, temporary necessities being smaller than the temporary resources that can be mobilized. The situation is favourable if one is consequence of acceleration of rotation of current assets, to emergency the receipts and relaxations used to pay otherwise; it can only be the result of temporary disruptions in supply and renewal of stocks.

In industrial enterprises it registers an NWC > 0, being necessary a net working capital of exploitation which is to be financed, and for distribution companies NWC $<\mathbf{0}$, are net financing resources, mining resources being higher borrowing.

D. Net Treasury (NT) shows the amount of money availability in an entity at a time, bank accounts or cash, being related to short-term financial transactions whose purpose is to provide resources for financing economic activity company. Positive net treasury represents the most conclusive expression of an activity effective.

Determination of net treasury is achieved by the difference between:

a) Working capital (WC) and necessary working capital (NWC):

$$
\text { NT = WC - NWC }
$$

b) Treasury active - passive Treasury directly:

\begin{tabular}{|ccc|}
\hline $\mathrm{NT}=$ & $\begin{array}{c}\text { Accounts receivable } \\
\text { balances and investment } \\
\text { availabilities }\end{array}$ & $-\quad \begin{array}{c}\text { Credit balances of } \\
\text { short-term loan accounts, } \\
\text { including account } 512\end{array}$ \\
\hline
\end{tabular}

The negative net treasury underlines the financial imbalance generated by the slow rotation of current assets, non-collection of receivables and appealing to foreign financial resources to ensure the conduct of business, leading to limitation of financial autonomy of the entity, stagnation or lack of further development, unfavourable situation. Treasury appears while the negative working capital is less than required for working capital cash loans that are greater than the availability of the firm reflecting mismanagement and poor economic condition.

The positive net treasury indicates financial balance, rhythm collection of receivables and current assets and rapid rotation occurs when the demand exceeds the working capital, namely when the availability of the cashier and bank loans exceeding treasury. The positive net treasury expresses a surplus funding that enriches the treasury and guarantees that the company operates in terms of efficiency of the existence of reserves in bank accounts and cash. Thus, creditors can always ensure that the company has at any time the possibility of financial debt repayment.

Colasse (2009) summarizes four cases evolving type of working capital (WC) and the need for working capital (NWC) (assuming that working capital changes only under the influence of the self-cash flow presented in Table 1).

The importance of financing decision lies primarily in providing short-term financial equilibrium, which means providing liquidity to meet commitments, that repayment of debts maturing in the near future. Secondly, the question of launching investment firm that lead to development opportunities. This case involves the financing of longterm development, conditioning results in the future growth and maintaining financial equilibrium. In general, the increase of own funds shall be made on the reserves of the favourable results obtained, and the cash contribution. It is also not neglected the selffinancing capacity of an enterprise that shapes the internal resources of these equity (stable resources) (Mociar, 2013). 
Table 1 Evolution of working capital, the necessary working capital and net treasury

\begin{tabular}{|c|c|c|c|}
\hline $\begin{array}{l}\text { CASE } \\
\text { no. } 1 \\
\text { Growth in } \\
\text { profitability }\end{array}$ & $\begin{array}{l}\text { - } \text { The need for } \\
\text { working capital } \\
\text { remains strictly } \\
\text { proportional } \\
\text { turnover } \\
\text { - } \text { Working capital } \\
\text { grows faster than } \\
\text { turnover } \\
\text { - Treasury negative } \\
\text { at first, becomes } \\
\text { positive }\end{array}$ & $\begin{array}{l}\text { Good management of } \\
\text { its various components } \\
\text { A good self-financing } \\
\text { capacity and good } \\
\text { profitability } \\
\text { Good management of } \\
\text { its various components } \\
\text { A good self-financing } \\
\text { capacity and good } \\
\text { profitability }\end{array}$ & $\begin{array}{l}\text { This is the case } \\
\text { of enterprise } \\
\text { whose growth is } \\
\text { accompanied by } \\
\text { a strengthening } \\
\text { of financial } \\
\text { equilibrium. }\end{array}$ \\
\hline $\begin{array}{l}\text { CASE } \\
\text { no. 2 } \\
\text { Bad run } \\
\text { growth }\end{array}$ & $\begin{array}{l}\text { - The need for } \\
\text { working capital } \\
\text { grows faster than } \\
\text { turnover } \\
\text { - Working capital } \\
\text { increased slightly in } \\
\text { relation to turnover } \\
\text { - Treasury remains } \\
\text { negative (deficit } \\
\text { increase cash) }\end{array}$ & $\begin{array}{l}\text { An inadequate } \\
\text { management of its } \\
\text { various components } \\
\text { Poor self-financing } \\
\text { capacity and } \\
\text { profitability } \\
\text { An inadequate } \\
\text { management of its } \\
\text { various components } \\
\text { Poor self-financing } \\
\text { capacity and } \\
\text { profitability }\end{array}$ & $\begin{array}{l}\text { This is the case } \\
\text { of enterprise in } \\
\text { growth, but } \\
\text { manages bad its } \\
\text { operating cycle. }\end{array}$ \\
\hline $\begin{array}{l}\text { CASE } \\
\text { no. } 3 \\
\text { Uncontrolled } \\
\text { stagnation }\end{array}$ & $\begin{array}{l}\text { - The need for } \\
\text { working capital } \\
\text { continues to } \\
\text { increase turnover } \\
\text { when stalled } \\
\text { - Working capital } \\
\text { decreases } \\
\text { - Treasury positive at } \\
\text { first, becomes } \\
\text { negative }\end{array}$ & $\begin{array}{l}\text { An inadequate } \\
\text { management of its } \\
\text { various components } \\
\text { Poor self-financing } \\
\text { capacity and } \\
\text { profitability }\end{array}$ & $\begin{array}{l}\text { This is the case } \\
\text { of an enterprise } \\
\text { that is stagnant, } \\
\text { loss-making, } \\
\text { which reduces } \\
\text { the working } \\
\text { capital but fails } \\
\text { to reduce the } \\
\text { need for } \\
\text { working capital. }\end{array}$ \\
\hline $\begin{array}{l}\text { CASE } \\
\text { no. } 4 \\
\text { Administred } \\
\text { recession but } \\
\text { loss generator }\end{array}$ & $\begin{array}{l}\text { - The need for } \\
\text { working capital is } \\
\text { rigorous } \\
\text { development of } \\
\text { turnover, } \\
\text { decreasing in } \\
\text { proportion to it } \\
\text { - Working capital } \\
\text { decreases due to the } \\
\text { decrease of } \\
\text { turnover that } \\
\text { generates losses. } \\
\text { Treasury positive at } \\
\text { first, becomes } \\
\text { negative }\end{array}$ & $\begin{array}{l}\text { Poor self-financing } \\
\text { capacity and } \\
\text { profitability }\end{array}$ & $\begin{array}{l}\text { It is the case of a } \\
\text { recession } \\
\text { enterprise that } \\
\text { generates losses } \\
\text { but still better } \\
\text { manage their } \\
\text { working capital, } \\
\text { but whose stable } \\
\text { resources } \\
\text { gradually } \\
\text { become } \\
\text { insufficient. }\end{array}$ \\
\hline
\end{tabular}

The principle to be applied to treasury management should be synonymous with that which applies to any other resources: "Minimize the size according to the needs you 
have to cover and achieve maximum effectiveness, by investing cash in investments that would reflect its unique characteristics" (Helfert, 2006).

\section{Conclusions}

Financial economic analysis is the tool by which managers know the situation at a time, the past one and can predict the future development of society by providing accurate and timely information in order to support decision-making and operational processes.

Financial equilibrium can be considered as (Popa, 2009):

a. Permanent imperative for any company in the sense that maintaining solvency is a restriction currently required to the company. If there are delays in payment of debt, or any mismatch, it may lead to injury and there is an urgent need for a correction;

b. Absolutely imperative that cannot be missed under any circumstances. For example, an enterprise from the economic practice that is in a difficult period can choose to give up some goals for growth, economic or social objectives, but may not waive the insurance objective of maintaining financial stability, the solvency objective that provides financial survival.

Net treasury as part of the financial balance has the role to inform managers about the degree of financial autonomy and the liquidity available to the company, which by default will allow repayment of debt and achieving efficient investments both money market and the financial one.

The importance of net cash flows from that it shows the amount of money available in an entity at a time, being related to short-term financial transactions whose purpose is to provide resources for financing the company's business. Determining net treasury involves calculation of working capital and necessary working capital, which make up the trio of financial equilibrium indicators, based on a horizontal balance sheet analysis that establishes correlations between efficient use of assets and financing them.

We concluded that it is very important to know the evolution of the indicators presented, because the company must follow the trend registered for an efficient management, being able to detect in time any inconsistency in optimal intervals and disruptive cases of normality, in order to improve the situation. Management decisions should be based on economic-financial values that characterize the company's performance and position. Managers can effectively place available funds in order to strengthen market position and increase the company's financial autonomy.

\section{References}

Andone, I., Georgescu, I., Toma, C., Solomon, D. C. (2013), Metodologia şi etica cercetării ştiinţifice în contabilitate şi sisteme informaţionale, Tehnopress Publishing House, Iaşi.

Căruntu, C. (2011), Profitability and Financial Stability, Annals of "Constantin Brâncuşi” University of Târgu Jiu, Economy Series, 3, 195-204.

Colasse, B. (2009), Analiza financiară a întreprinderii, translated by Tabără, N., Tipo Moldova Publishing House, Iaşi.

Helfert, E. (2006), Techniques of financial analysis a guide to value creation, BMT Publishing House, Bucharest. 
Mironiuc, M. (2009), Analiză economico-financiară, “Alexandru Ioan Cuza” University Publishing House, Iaşi.

Mociar, I. (2013), Managementul financiar şi finanţarea internă a întreprinderii, Gestiunea şi contabilitatea firmei, 1, Tribuna Economică Publishing House, Bucharest, available on http://tribunaeconomica.ro/blog/?p=908\# sthash.lufyup48.dpuf.

Order of the Ministry of Public Finance No. 3055/2009 approving the Accounting Regulations compliant with the European Directives, published in the Official Journal of Romania No. 766 bis of November 10, 2009 (RO).

Paraschivescu, D., Păvăloaia, W., Radu, F., Fotache, G., Patraşcu, L., Bordeianu, G. D., Grosu, O. (2013), Contabilitate: fundamente, aplicații, istorie și personalități, Tehnopress Publishing House, Iaşi.

Păvăloaia, W., Păvăloaia, D. (2009), Analiza economico-financiară, Tehnopress Publishing House, Iaşi.

Petrescu, S. (2012), Evaluarea economică și financiară a întreprinderii. Conceptemetode-procedee, Tehnopress Publishing House, Iaşi.

Popa, I. L. (2009), Analiză economico-financiară, Mirton Publishing House, Timişoara.

Solomon, D. C. (2004), Analiza statica a echilibrului financiar pe baza bilanţului, Buletin ştiinţific, 2, Year VII, “George Bacovia” University of Bacău, 291-300. 